agriTECH, 40 (1) 2020, 21-30

\title{
Rancang Bangun Computer Vision System (CVS) sebagai Instrumen Pengukuran Warna Buah
}

\author{
Design of A Computer Vision System (CVS) as An Instrument for Measuring Fruits Color \\ Ferlando Jubelito Simanungkalit*, Rosnawyta Simanjuntak \\ Program Studi Teknologi Hasil Pertanian, Fakultas Pertanian, Universitas HKBP Nommensen Medan, \\ Jl. Sutomo No. 4A Medan, North Sumatera, Indonesia 20234 \\ *Penulis korespondensi: Ferlando J.S., Email: ferlandosimanungkalit@uhn.ac.id
}

Tanggal submisi: 19 Oktober 2017; Tanggal penerimaan: 9 Oktober 2019

\begin{abstract}
ABSTRAK
Warna mempunyai korelasi dengan penampilan fisik, kandungan gizi, kimiawi serta sifat-sifat sensoris yang sangat menentukan kualitas produk-produk pertanian dan bahan pangan. Oleh sebab itu, pengukuran warna memiliki peran yang sangat penting di dalam industri pangan dan pengolahan produk-produk hasil pertanian. Pengukuran warna secara konvensional dilakukan secara destruktif dengan menggunakan peralatan laboratorium. Metode pengukuran warna produk-produk hasil pertanian yang lebih cepat, akurat dan tidak merusak (non-destruktif) menjadi sebuah kebutuhan. Penelitian ini bertujuan mengembangkan Computer Vision System (CVS) yang dapat digunakan sebagai alat untuk mengukur warna buah-buahan. CVS yang dirancang terdiri dari mini photo studio berwarna hitam berukuran 60x60x60 cm; pencahayaan dari 2 unit lampu LED 15 watt, kamera digital sony a6000, seperangkat laptop dan software aplikasi pengolahan citra. Software pengolahan citra dikembangkan dengan menggunakan bahasa pemrograman VB.Net 2008. CVS yang dikembangkan dikalibrasi dengan menggunakan 24 grafik warna Macbeth Colorchecker (Gretag-Macbeth, USA). Hasil validasi dari 24 grafik warna Macbeth Colorchecker yang diukur dengan menggunakan aplikasi pengolah citra menghasilkan nilai MAPE (Mean Absolute Percentage Error) komponen R/Red $=0 \%$; G/Green $=0 \%$ dan $\mathrm{B} /$ Blue $=0,5 \%$; dengan akurasi $99 \%$. Dalam pengukuran warna, CVS yang dikembangkan memiliki tingkat akurasi $95 \%$.
\end{abstract}

Kata kunci: Pengukuran warna; computer vision system; CVS; pengolahan citra

\begin{abstract}
Color had a correlation with physical appearance, nutritional and chemical content as well as sensory properties which determine the quality of agricultural products and foods. Conventional color measurements were performed destructively using laboratory equipment. Therefore, color measurement methods of agricultural products were needed more quickly, accurately and non-destructively. This study aimed to develop a Computer Vision System (CVS) that can be used as a tool to measure the color of fruits. The designed CVS consists of a $60 \times 60 \times 60 \mathrm{~cm}$ black mini photo studio; a pair 15 watt LED lighting, sony a6000 digital camera, a set of laptop and an image processing software applications. Image processing software was programmed using VB.Net 2008 programming language. The developed CVS was calibrated using 24 color charts Macbeth Colorchecker (Gretag-Macbeth, USA). The calibration results of 24 color chart of Macbeth Colorchecker was resulted in a MAPE (Mean Absolute Percentage Error) value of component R / Red $=0 \%$; G / Green $=0 \%$ and B / Blue $=0,5 \%$; with $99 \%$ accuracy rate. In color measurement, the developed CVS had a $95 \%$ accuracy rate.
\end{abstract}

Keywords: Color measurement; computer vision system; CVS; image processing

DOI: http://doi.org/10.22146/agritech.29102

ISSN 0216-0455 (Print), ISSN 2527-3825 (Online) 


\section{PENDAHULUAN}

Kualitas eksternal merupakan atribut kualitas inderawi dan yang paling penting dalam menilai mutu produk hasil pertanian. Dalam kehidupan sehari-hari, kualitas ekternal buah-buahan diukur dari warna, tekstur, ukuran, bentuk dan cacat yang terlihat secara visual (Costa dkk., 2011). Penampilan eksternal buah mempengaruhi nilai jual dan perilaku konsumen. Buahbuahan yang rusak, terinfeksi mikroorganisme dan terkontaminasi bahan tercemar dapat menyebarkan infeksi dan kontaminan ke produk-produk yang baik. Bahkan sampai ke seluruh batch hasil produksi, sehingga menyebabkan kerugian ekonomi yang besar, terlebih masalah keamanan pangan (Li dkk., 2011). Pemeriksaan kualitas eksternal dan sistem pengkelasan mutu menjadi sangat dibutuhkan dan harus dilakukan untuk memastikan mutu produk hasil pertanian dalam proses pengelolaan pascapanen (Teena dkk., 2013). Penampilan keseluruhan dari suatu produk pertanian dinilai dengan mempertimbangkan ukuran, bentuk, warna, kondisi kesegaran dan ketiadaan cacat atau lebam.

Warna adalah atribut kualitas yang pertama dievaluasi oleh konsumen, dan merupakan atribut kualitas bahan pangan yang paling mempengaruhi tingkat penerimaan pasar. Pengukuran warna bahan pangan yang objektif sangat diperlukan dalam proses menentukan pemastian mutu dan pengkelasan mutu produk hasil pertanian (Wu dan Sun, 2013). Warna merupakan atribut kualitas sensoris yang paling penting dari produk buah-buahan, dan menjadi faktor pertama yang mempengaruhi konsumen untuk memilih atau menolak produk buah-buahan. Warna buah dipengaruhi oleh kandungan biokimia internal, mikrobiologi, perubahan fisik dan kimia yang terjadi selama proses pertumbuhan, tingkat kematangan, pengelolaan pascapanen dan tahap produksi. Oleh sebab itu, pemeriksaan warna telah digunakan sebagai metode pengukuran tidak langsung dari beberapa atribut kualitas internal seperti kematangan, kesegaran, tingkat keragaman dan kesukaan, serta keamanan pangan (Pathare dkk., 2013). Beberapa hasil penelitian menunjukkan bahwa warna memiliki keterkaitan dengan respon manusia (Iqbal dkk., 2010). Karena persyaratan mengenai kualitas yang ditetapkan oleh konsumen semakin meningkat, maka industri pangan telah membiayai banyak usaha untuk mengukur dan mengelola warna dari produk-produk yang dihasilkan. Dengan demikian, sangat penting untuk mengembangkan sistem pemeriksaan warna yang dapat memproses pengukuran warna secara cepat dan objektif selama proses penanganan dan periode penyimpanan (Pallottino dkk., 2010).
Operasi pemeriksaan kualitas eksternal buahbuahan secara manual memiliki beberapa kelemahan seperti inkonsistensi hasil pengukuran, proses pemeriksaan memakan waktu yang lebih lama, serta variasi dan subjektivitas hasil pemeriksaan. Selain itu, proses manual juga sangat membosankan, melelahkan, mahal, dan mudah dipengaruhi oleh lingkungan sekitarnya. Maka sangat penting dan perlu untuk mengembangkan sistem inspeksi kualitas eksternal buah dan sayuran secara otomatis untuk menggantikan sistem pemeriksaan manual (Elmasry dkk., 2012a; Elmasry dkk., 2012b; Razmjooy dkk., 2012).

Sebagian besar pemeriksaan atribut kualitas eksternal buah dan sayuran masih dilakukan secara manual menggunakan indera penglihatan. Computer Vision systems (CVS) memiliki kemampuan untuk melakukan pemeriksaan atribut kualitas eksternal buah dan sayuran secara otomatis. Dalam lingkungan pemeriksaan visual seperti ini, analisis tampilan eksternal buah-buahan dalam beberapa aspek kriteria merupakan pekerjaan yang berkelanjutan. CVS merupakan metode yang paling cocok untuk digunakan dalam menganalisis kualitas eksternal dan penjaminan mutu (Bhargava dan Bansal, 2018). CVS adalah rekayasa teknologi yang menggabungkan rekayasa teknologi mekanik, instrumentasi optik, penginderaan elektromagnetik, teknologi video digital dan teknologi pengolahan citra (Patel dkk., 2012). CVS adalah produk ilmu pengetahuan dan teknologi yang bertanggung jawab untuk mengembangkan studi dan metode penerapan yang memungkinkan komputer untuk memahami informasi dari citra/video, dan interpretasikannya dengan karakteristik tertentu untuk tujuan tertentu (Freitas dkk., 2012).

CVS telah dikembangkan sebagai alat inspeksi ilmiah untuk pemeriksaan kualitas dan keamanan berbagai produk pangan dan hasil pertanian. Dalam pemeriksaan kualitas eksternal buah dan sayuran secara otomatis, teknologi ini bertujuan untuk menduplikasi efek penglihatan manusia secara elektronik untuk mempersepsikan dan memahami citra visual, mengenali dan menafsirkan karakter kualitas eksternal buah dan sayuran, serta menyediakan informasi yang diperlukan untuk menjalankan mesin sortasi dan pengkelasan mutu (Zhang dkk., 2014). CVS terdiri dari kamera digital atau kamera video digital yang digunakan sebagai instrumen pengambilan citra, pencahayaan, komputer dan perangkat lunak komputer untuk aplikasi pengolahan citra (Brosnan dan Sun, 2004).

Warna bagian-bagian di dalam piksel suatu citra digital diekspresikan dalam tiga koordinat model ruang warna. Warna primer merah, hijau dan biru (RGB) adalah yang paling banyak digunakan dalam aplikasi 
CVS (Vidal dkk., 2013). Karena mata manusia peka terhadap gelombang warna primer (merah, hijau dan biru), CVS tradisional yang paling umum digunakan dalam pemeriksaan warna biasanya berbasis pada kamera warna RGB ( $R$ = red/merah; $G=$ green/hijau; $\mathrm{B}=$ blue/biru) yang meniru penglihatan mata manusia dengan menangkap gambar menggunakan tiga filter yang berpusat pada panjang gelombang RGB (Lorente dkk., 2012).

Citra berwarna digital direpresentasikan dalam bentuk ruang warna RGB yang terdiri dari tiga komponen per piksel dalam kisaran 0-255 dan disimpan secara konvensional dalam ukuran delapan bit per komponen warna. Ketiga intensitas citra ( $R, G$ dan $B$ ) ini kemudian dikombinasikan secara elektronik untuk menghasilkan citra digital berwarna (Russ, 2004).

Saat citra berwarna dari buah diambil dengan menggunakan kamera digital, citra tersebut berada dalam model ruang warna RGB. Model ruang warna RGB adalah model aditif. Warna merah, hijau, dan biru (sering digunakan dalam model lampu tambahan) dikombinasikan dalam berbagai cara untuk mereproduksi warna yang lain. Nama model dan singkatan 'RGB' berasal dari tiga warna utama, merah, hijau, dan biru (Red, Green, Blue). Secara umum, model warna RGB menggambarkan persepsi kita tentang warna. Tiga jenis reseptor di retina mata manusia memiliki sensitivitas kepekaan yang sesuai dengan tiga warna primer ini. Model ruang warna RGB mewakili warna dalam volume kubik yang ditentukan oleh sumbu ortogonal Merah, Hijau, dan Biru. Hitam adalah asal dari sistem koordinat $(R=G=B=0)$, dan putih berada di sudut yang berlawanan dari kubus $(R=G=B=255)$. Diagonal yang menghubungkan sudut hitam dan putih (garis putus-putus) berisi kisaran tingkat abu-abu netral (Wang dkk., 2009).

Wang dkk. (2009) menggunakan model ruang warna RGB sebagai input dalam pengukuran dan evaluasi kualitas internal buah pisang secara nondestruktif. Hasil penelitian menunjukkan bahwa kombinasi antara model ruang warna RGB dan jaringan saraf tiruan backpropagation merupakan metode yang handal dan layak untuk digunakan sebagai metode pengukuran dan evaluasi kualitas internal buah-buahan. Blasco dkk. (2009) menggunakan metode RGB yang dikembangkan dalam model R/G ratio untuk mengklasifikasikan empat kategori buah delima. Hasil penelitian menunjukkan bahwa CVS yang dikembangkan berhasil mengklasifikasikan buah delima dengan tingkat kesuksesan yang sama dengan hasil klasifikasi menggunakan pemeriksaan visual.

Garrido-novell dkk. (2012) mengklasifikasikan apel menjadi empat kelompok berdasarkan warna menggunakan fitur RGB sebagai prediktor dan analisis diskriminan linier. Hasil penelitian menunjukkan metode ini dapat mengklasifikasikan apel dengan tingkat keberhasilan klasifikasi mencapai 66,2\%. Vidal dkk. (2013) membandingkan dua algoritma yang berbeda untuk mengukur warna buah jeruk menggunakan CVS yang dikembangkan untuk sistem sortasi perangkat mobile. Hasil penelitian menunjukkan bahwa algoritma pengukuran warna buah jeruk menggunakan nilai ratarata RGB (sistem PIX-CCI) lebih cepat dan lebih dapat diandalkan dengan korelasi hasil pengukuran mencapai 92,51\%. Masithoh dkk. (2011) mengembangkan CVS sederhana untuk menentukan kualitas tomat secara non-destruktif berdasarkan parameter warna RGB. Hasil pengukuran parameter RGB yang dihasilkan oleh CVS divalidasi dengan menggunakan Adobe Photoshop CS2. Validasi menunjukkan bahwa hasil pengukuran parameter RGB yang dihasilkan oleh CVS tidak berbeda nyata dengan hasil pengukuran parameter RGB menggunakan Adobe Photoshop CS2.

\section{METODE PENELITIAN}

Penelitian ini terdiri dari dua tahap, yaitu pembuatan instrumen penangkap citra (perangkat akuisisi citra) dan pembuatan perangkat lunak pengolah citra digital untuk mengukur nilai komponen RGB (Red Green Blue) dari citra digital yang diobservasi. CVS yang dibangun terdiri dari (1) mini photo studio sebagai perangkat untuk meletakkan objek dalam proses pengambilan citra digital, (2) kamera digital untuk mendapatkan citra objek dalam format digital, (3) sumber pencahayaan yang berasal dari dua unit lampu Light Emitting Diode (LED) sepanjang $40 \mathrm{~cm}$, masing-masing berdaya 15W, (4) laptop dan aplikasi perangkat lunak Remote Imaging Edge sebagai perangkat untuk mengoperasikan shutter kamera secara nirkabel (wifi), (5) laptop sebagai perangkat untuk menyimpan citra digital dan mengolah data, beserta monitor untuk menampilkan tampilan citra digital dan aplikasi pengolah citra, dan (6) aplikasi pengolah citra yang berfungsi mengukur nilai RGB dari objek yang diobservasi di dalam citra digital.

Mini photo studio sebagai perangkat untuk meletakkan objek dalam proses pengambilan citra digital (pemotretan) dibentuk dari rangka besi dan ditutupi dengan dinding kanvas berwarna hitam (kain terpal), berukuran $60 \times 60 \times 60 \mathrm{~cm}^{3}$. Seluruh dinding permukaan bagian dalam dari mini photo studio menggunakan kain terpal berwarna hitam. Mini photo studio memiliki pintu di bagian depan untuk memudahkan pengoperasian peralatan dan penempatan objek. Objek yang diobservasi diletakkan didasar mini photo studio, tegak lurus dengan lensa kamera digital yang berada di atasnya (Masithoh dkk., 2011; Girolami dkk., 2013). 
Pada bagian atas mini photo studio dipasang perangkat pencahayaan yang terdiri dari 2 unit lampu LED berukuran $40 \mathrm{~cm}$, yang masing-masing berdaya 15 watt. Lampu LED dipasang pada bagian atas mini photo studio, dengan jarak $40 \mathrm{~cm}$ dari dasar dan pada posisi $90^{\circ}$ dari objek foto yang terletak di bagian bawahnya. Lampu LED terhubung dengan rangkaian light dimmer circuit yang merupakan rangkaian pengatur terang gelapnya lampu, sehingga membuat intensitas pencahayaan lampu LED dapat diatur sesuai dengan kebutuhan. Dalam penelitian ini, intensitas cahaya yang digunakan mengikuti penelitian Masithoh dkk., 2011 sebesar 189 lux. Intensitas cahaya yang dihasilkan oleh lampu LED di dalam ruang mini photo studio diukur dari dasar mini photo studio, menggunakan digital lux meter.

Sensor akuisisi citra yang digunakan adalah kamera Sony a6000 dengan lensa $16-50 \mathrm{~mm} f / 3,5-$ 5,6 lens, tipe sensor CMOS 24,3 MP yang menghasilkan citra digital dengan ukuran 1616×1080 piksel. Posisi kamera berada tegak lurus di atas objek yang akan difoto dengan jarak lensa berkisar $40 \mathrm{~cm}$ dari objek foto. Pengaturan kamera diatur menggunakan manual operation mode dengan shutter speed $1 / 6 \mathrm{~s}$, aperture Av F/11.0, ISO velocity 100 , flash off, focal distance 30 mm (Girolami dkk., 2013). Pengoperasian shutter kamera dilakukan secara nirkabel (wifi) dari laptop dengan menggunakan software Remote Imaging Edge, yaitu aplikasi yang dikeluarkan oleh Sony sebagai aplikasi untuk mengendalikan shutter kamera Sony dari perangkat seluler ataupun desktop. Citra objek yang ditangkap dan diproyeksikan oleh kamera secara otomatis langsung terkirim ke dalam ruang penyimpanan data (harddisk) laptop dan kemudian terhubung dengan aplikasi pengolah citra.

Citra digital yang telah ditransfer oleh kamera ke dalam harddisk laptop kemudian digunakan oleh aplikasi pengolah citra untuk keperluan pengukuran nilai RGB. Aplikasi perangkat lunak pengolah citra CVS dikembangkan dengan menggunakan bahasa pemrograman VB.Net 2008. Aplikasi pengolah citra digital dikembangkan untuk mengukur nilai RGB ratarata dari objek yang terdapat di dalam citra digital. Pengukuran nilai RGB dilakukan setelah proses segmentasi citra (pemisahan objek dari background) selesai dilakukan. Pengukuran nilai RGB dari citra digital mengikuti Persamaan 1 sampai dengan 3.

Pengukuran nilai komponen warna merah (Red) $r=\frac{R}{R+G+B}$ (1)
Pengukuran nilai komponen warna hijau (Green) $g=\frac{G}{R+G+B}$ (2)
Pengukuran nilai komponen warna biru (Blue) $b=\frac{B}{R+G+B}$
Dimana $\mathrm{R}$ adalah jumlah nilai komponen warna merah (Red) dari seluruh piksel citra $\sum_{i=1}^{n} R_{i} ; \mathrm{G}$ adalah jumlah nilai komponen warna hijau (Green) dari seluruh piksel citra $\sum_{i=1}^{n} G_{i} ; \mathrm{B}$ adalah jumlah nilai komponen warna biru (Blue) dari seluruh piksel citra $\sum_{i=1}^{n} B_{i} ;$ dan $\mathrm{n}$ adalah jumlah seluruh piksel penyusun citra digital (Xiaobo dkk., 2007).

Validasi hasil pengukuran nilai RGB yang dihasilkan oleh aplikasi pengolah citra dilakukan dengan menggunakan 24 grafik warna Macbeth Colorchecker (Gretag-Macbeth, USA) seperti yang dilakukan oleh Girolami dkk. (2013) dalam penelitiannya mengukur warna daging menggunakan CVS. Adapun ke-24 warna Macbeth Colorchecker terdiri dari darkskin, lightskin, blue sky, foliage, blue flower, bluish green, orange, purplish blue, moderate red, purple, yellow green, orange yellow, blue, green, red, yellow, magenta, cyan, white 9.5, neutral 8, neutral 6.5, neutral 5, neutral 3.5 dan black 2. Adobe Photoshop CS6 (selanjutnya disebut photoshop) digunakan sebagai software untuk menghasilkan grafik warna Macbeth Colorchecker sesuai dengan koordinat RGB Adobe 8-bit yang telah dikembangkan oleh Danny Pascale (Pascale, 2006). Sejumlah 24 grafik warna Macbeth Colorchecker berukuran 500x500 piksel dibuat dengan menggunakan photoshop, kemudian disimpan dalam format JPEG (Joint Photographic Experts Group). Softcopy file JPEG dari 24 grafik warna Macbeth Colorchecker yang dihasilkan oleh photoshop kemudian diukur nilai komponen RGB-nya menggunakan aplikasi pengolah citra CVS. Hasil pengukuran aplikasi pengolah citra CVS kemudian dibandingkan dengan nilai koordinat RGB grafik warna Macbeth Colorchecker saat dibuat menggunakan photoshop.

Validasi kemampuan CVS dalam proses pengukuran warna dilakukan dengan cara mencetak file JPEG dari 24 grafik warna Macbeth Colorchecker yang dihasilkan oleh photoshop ke dalam kertas foto injek tipe Fujifilm Silky Satin Doff 235 gram ukuran A4 (210 x 297 mm) menggunakan printer Epson L360. Hasil cetakan dari 24 warna Macbeth Colorchecker kemudian difoto dengan menggunakan CVS. Foto digital dari 24 grafik warna Macbeth Colorchecker kemudian diukur nilai RGB-nya menggunakan aplikasi pengolah citra CVS. Aplikasi pengolah citra CVS mengukur nilai RGB ratarata dari objek grafik warna Macbeth Colorchecker yang terdapat di dalam piksel citra digital. Hasil pengukuran nilai RGB rata-rata yang dihasilkan oleh CVS kemudian dibandingkan dengan hasil pengukuran photoshop. Metode validasi hasil pengukuran nilai RGB yang dihasilkan CVS dengan menggunakan photoshop juga digunakan dalam penelitian Girolami dkk. (2013) dan Masithoh dkk. (2011). Waktu pengambilan data dalam 
proses validasi pengukuran warna CVS dilakukan pada bulan September tahun 2018.

\section{HASIL DAN PEMBAHASAN}

\section{Pengembangan CVS}

CVS yang dikembangkan tampak seperti Gambar 1 dan terdiri dari (1) mini photo studio berukuran $60 \times 60 \times 60 \mathrm{~cm}$ yang seluruhnya terbuat dari kain kanvas berwarna hitam dan digunakan sebagai perangkat pengambilan citra digital; (2) kamera digital Sony a6000 dengan lensa 16 - $50 \mathrm{~mm}$ f/3.5 - 5.6 lens, tipe sensor CMOS 24,3 MP yang menghasilkan citra digital dengan ukuran 1616×1080 piksel dalam format JPEG. Posisi kamera berada tegak lurus di atas objek yang akan difoto dengan jarak lensa berkisar $40 \mathrm{~cm}$ dari objek foto. Pengaturan kamera diatur menggunakan manual operation mode dengan shutter speed $1 / 6 \mathrm{~s}$, aperture Av F/11.0, ISO velocity 100 , flash off, focal distance $30 \mathrm{~mm}$ (Girolami dkk., 2013). Kamera digital digunakan sebagai perangkat untuk mendapatkan citra objek dalam format digital; (3) sumber pencahayaan yang berasal dari dua unit lampu Light Emitting Diode (LED) sepanjang 40 $\mathrm{cm}$, masing-masing berdaya 15W. Lampu LED dipasang pada bagian atas mini photo studio, dengan jarak 40 $\mathrm{cm}$ dari dasar dan pada posisi $90^{\circ}$ dari objek foto yang terletak di bagian bawahnya. Lampu LED terhubung dengan rangkaian light dimmer circuit yang merupakan rangkaian pengatur terang gelapnya lampu, sehingga membuat intensitas pencahayaan lampu LED dapat diatur sesuai dengan kebutuhan. Intensitas cahaya yang dihasilkan oleh lampu LED diatur sebesar 189 lux dengan menggunakan rangkaian light dimmer circuit; (4) laptop dan aplikasi perangkat lunak Remote Imaging Edge sebagai perangkat untuk mengoperasikan shutter kamera secara nirkabel (wifi); (5) laptop sebagai perangkat untuk menyimpan citra digital dan mengolah data, beserta monitor untuk menampilkan tampilan citra digital dan aplikasi pengolah citra, dan (6) aplikasi pengolah citra yang berfungsi mengukur nilai RGB dari objek yang diobservasi di dalam citra digital.

Citra digital dari objek yang diamati difoto menggunakan CVS, hasilnya dikirimkan ke laptop untuk diolah dengan aplikasi pengolah citra CVS yang diprogram dengan Bahasa pemrograman VB.Net 2008. Gambar 2 merupakan tampilan antar muka atau graphical user interface (GUI) dari aplikasi perangkat lunak pengolah citra CVS yang dikembangkan. Bagianbagian dari GUI ini menampilkan citra hasil Segmentasi (pemisahan objek dari backgroundnya), nilai rata-rata komponen Red Green Blue (RGB) dari citra yang telah disegmentasi, dan tabel nilai komponen RGB dari setiap

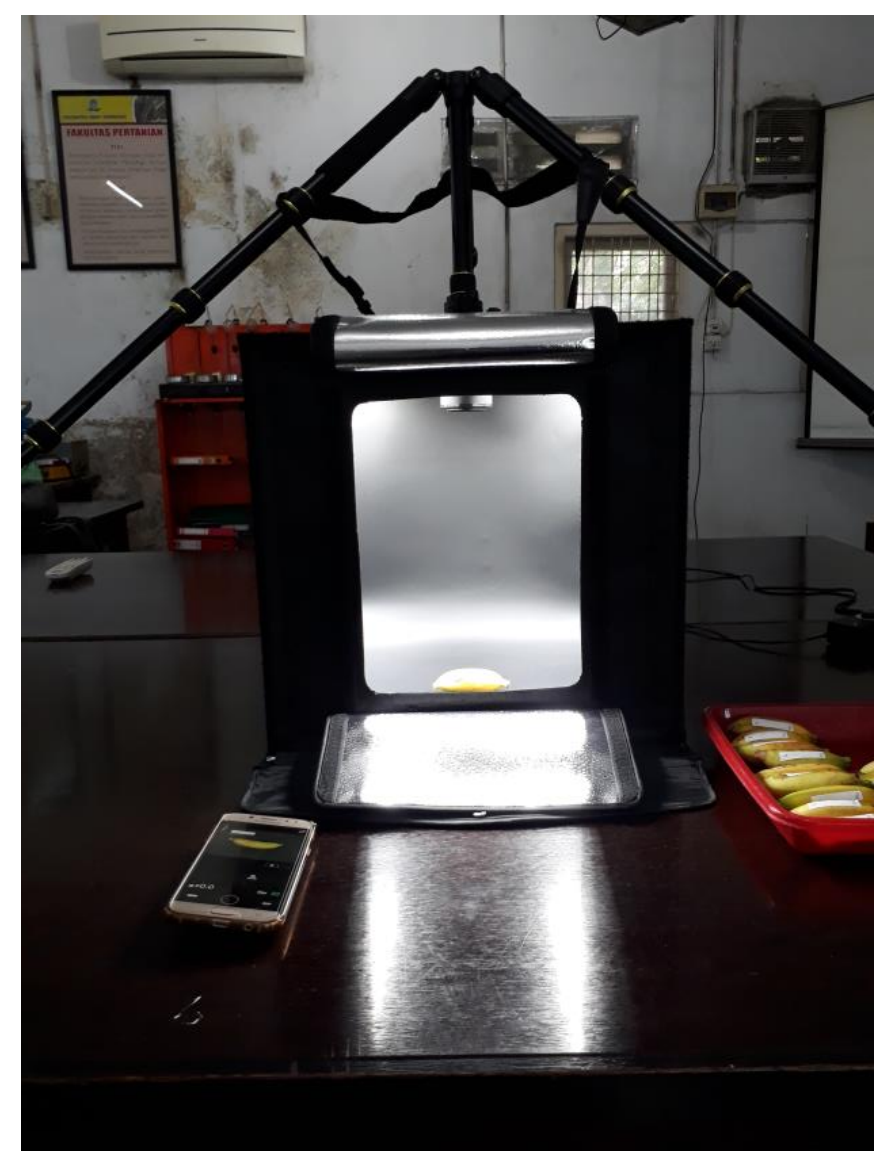

Gambar 1. Computer vision system (CVS) yang dikembangkan

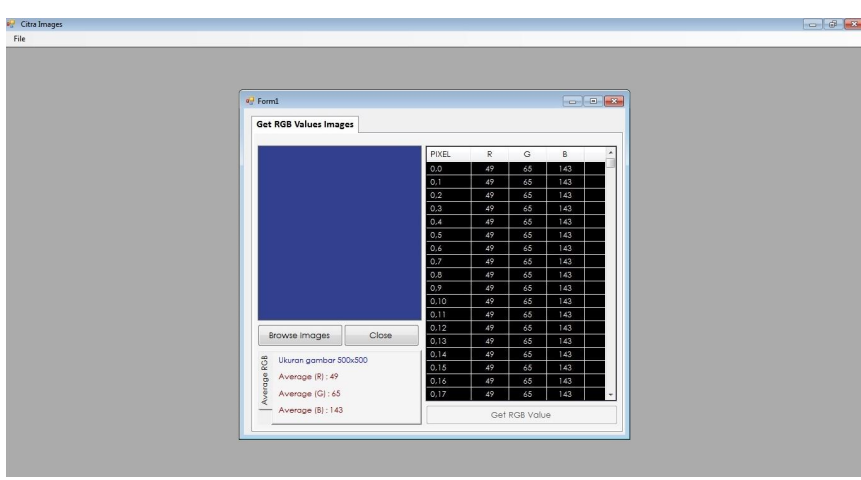

Gambar 2. Graphical user interface (GUI) aplikasi pengolah citra CVS yang dikembangkan digunakan untuk mengukur file JPEG dari grafik warna Macbeth Colorchecker blue $(R=49, G=65, B=143)$

piksel citra. Pengolahan citra yang dilakukan oleh aplikasi pengolah citra CVS adalah mengukur nilai komponen warna RGB dari citra objek yang telah disegmentasi dari backgroundnya.

\section{Validasi Aplikasi Pengolah Citra CVS}

Adobe Photoshop CS6 digunakan sebagai software untuk menghasilkan file JPEG dari 24 grafik warna 
Macbeth Colorchecker yang masing-masing berukuran 500x500 piksel sesuai dengan koordinat RGB Adobe 8-bit yang telah dikembangkan oleh Danny Pascale (Pascale, 2006). Softcopy file JPEG dari 24 grafik warna Macbeth Colorchecker yang dihasilkan oleh photoshop kemudian diukur nilai komponen RGB-nya menggunakan aplikasi pengolah citra CVS. Hasil pengukuran aplikasi pengolah citra CVS kemudian dibandingkan dengan nilai koordinat RGB Macbeth Colorchecker saat dibuat menggunakan photoshop. Adapun hasil pengukuran validasi aplikasi pengolah citra CVS seperti pada Tabel 1 .

Hasil validasi menunjukkan bahwa pengukuran warna yang dilakukan oleh aplikasi pengolah citra CVS tidak berbeda nyata dengan koordinat RGB file JPEG dari grafik warna Macbeth Colorchecker yang dibuat dengan menggunakan photoshop. Persentase kesalahan tertinggi untuk komponen $\mathrm{R}=1,3 \%, \mathrm{G}=1,6 \%$ dan $\mathrm{B}$ $=1,9 \%$. Kesalahan rata-rata dari 24 pengukuran file JPEG grafik warna Macbeth Colorchecker $\mathrm{R}=0 \%, \mathrm{G}=$ $0 \%$ dan $\mathrm{B}=0,5 \%$. Hasil validasi menunjukkan bahwa aplikasi pengolah citra yang dihasilkan mempunyai akurasi di atas $99 \%$. Hasil ini sejalan dengan penelitian Masithoh dkk., 2011 dimana hasil pengukuran nilai komponen RGB yang dihasilkan oleh CVS tidak berbeda nyata dengan hasil pengukuran yang dihasilkan oleh Adobe Photoshop CS3.

\section{Validasi CVS}

Validasi CVS dilakukan dengan membandingkan hasil pengukuran nilai komponen RGB dari foto objek

Tabel 1. Hasil validasi aplikasi pengolah citra CVS menggunakan 24 grafik warna Macbeth Colorchecker

\begin{tabular}{|c|c|c|c|c|c|c|c|c|c|c|c|c|c|}
\hline \multirow[t]{2}{*}{ No } & \multirow[t]{2}{*}{ Warna } & \multicolumn{3}{|c|}{$\begin{array}{c}\text { Macbeth } \\
\text { Colorchecker } \\
\text { (Adobe) (A) }\end{array}$} & \multicolumn{3}{|c|}{ CVS (B) } & \multicolumn{3}{|c|}{$\begin{array}{c}\text { Error } \\
(\mathrm{C}=\mathrm{B}-\mathrm{A})\end{array}$} & \multicolumn{3}{|c|}{$\begin{array}{c}\% \text { Error } \\
\left((\mathrm{C} / \mathrm{A})^{*} 100 \%\right)\end{array}$} \\
\hline & & $\mathrm{R}$ & $\mathrm{G}$ & $B$ & $\mathrm{R}$ & $\mathrm{G}$ & $B$ & $\mathrm{R}$ & $\mathrm{G}$ & $B$ & $\mathrm{R}$ & $\mathrm{G}$ & $B$ \\
\hline 1 & Dark skin & 107 & 82 & 70 & 108 & 81 & 70 & 1 & -1 & 0 & $0,9 \%$ & $1,2 \%$ & $0,0 \%$ \\
\hline 2 & Light skin & 184 & 146 & 129 & 184 & 147 & 129 & 0 & 1 & 0 & $0,0 \%$ & $0,7 \%$ & $0,0 \%$ \\
\hline 3 & Blue sky & 101 & 122 & 153 & 101 & 122 & 153 & 0 & 0 & 0 & $0,0 \%$ & $0,0 \%$ & $0,0 \%$ \\
\hline 4 & Foliage & 95 & 107 & 69 & 95 & 107 & 69 & 0 & 0 & 0 & $0,0 \%$ & $0,0 \%$ & $0,0 \%$ \\
\hline 5 & Blue flower & 128 & 127 & 173 & 129 & 127 & 174 & 1 & 0 & 1 & $0,8 \%$ & $0,0 \%$ & $0,6 \%$ \\
\hline 6 & Bluish green & 129 & 188 & 171 & 130 & 188 & 173 & 1 & 0 & 2 & $0,8 \%$ & $0,0 \%$ & $1,2 \%$ \\
\hline 7 & Orange & 201 & 123 & 56 & 202 & 123 & 57 & 1 & 0 & 1 & $0,5 \%$ & $0,0 \%$ & $1,8 \%$ \\
\hline 8 & Purplish blue & 77 & 92 & 166 & 78 & 92 & 165 & 1 & 0 & -1 & $1,3 \%$ & $0,0 \%$ & $0,6 \%$ \\
\hline 9 & Moderate red & 174 & 83 & 97 & 174 & 83 & 98 & 0 & 0 & 1 & $0,0 \%$ & $0,0 \%$ & $1,0 \%$ \\
\hline 10 & Purple & 86 & 61 & 104 & 87 & 62 & 104 & 1 & 1 & 0 & $1,2 \%$ & $1,6 \%$ & $0,0 \%$ \\
\hline 11 & Yellow green & 167 & 188 & 75 & 168 & 188 & 75 & 1 & 0 & 0 & $0,6 \%$ & $0,0 \%$ & $0,0 \%$ \\
\hline 12 & Orange yellow & 213 & 160 & 55 & 213 & 160 & 56 & 0 & 0 & 1 & $0,0 \%$ & $0,0 \%$ & $1,8 \%$ \\
\hline 13 & Blue & 49 & 65 & 143 & 49 & 65 & 143 & 0 & 0 & 0 & $0,0 \%$ & $0,0 \%$ & $0,0 \%$ \\
\hline 14 & Green & 99 & 148 & 80 & 99 & 149 & 80 & 0 & 1 & 0 & $0,0 \%$ & $0,7 \%$ & $0,0 \%$ \\
\hline 15 & Red & 155 & 52 & 59 & 156 & 52 & 59 & 1 & 0 & 0 & $0,6 \%$ & $0,0 \%$ & $0,0 \%$ \\
\hline 16 & Yellow & 227 & 197 & 52 & 228 & 198 & 52 & 1 & 1 & 0 & $0,4 \%$ & $0,5 \%$ & $0,0 \%$ \\
\hline 17 & Magenta & 169 & 85 & 147 & 169 & 85 & 147 & 0 & 0 & 0 & $0,0 \%$ & $0,0 \%$ & $0,0 \%$ \\
\hline 18 & Cyan & 61 & 135 & 167 & 61 & 136 & 168 & 0 & 1 & 1 & $0,0 \%$ & $0,7 \%$ & $0,6 \%$ \\
\hline 19 & White 9,5 & 245 & 245 & 242 & 245 & 245 & 243 & 0 & 0 & 1 & $0,0 \%$ & $0,0 \%$ & $0,4 \%$ \\
\hline 20 & Neutral 8 & 200 & 201 & 201 & 200 & 201 & 202 & 0 & 0 & 1 & $0,0 \%$ & $0,0 \%$ & $0,5 \%$ \\
\hline 21 & Neutral 6,5 & 160 & 161 & 162 & 160 & 161 & 163 & 0 & 0 & 1 & $0,0 \%$ & $0,0 \%$ & $0,6 \%$ \\
\hline 22 & Neutral 5 & 120 & 120 & 121 & 120 & 120 & 122 & 0 & 0 & 1 & $0,0 \%$ & $0,0 \%$ & $0,8 \%$ \\
\hline 23 & Neutral 3,5 & 84 & 85 & 86 & 84 & 85 & 87 & 0 & 0 & 1 & $0,0 \%$ & $0,0 \%$ & $1,2 \%$ \\
\hline \multirow[t]{2}{*}{24} & Black 2 & 52 & 53 & 54 & 52 & 53 & 55 & 0 & 0 & 1 & $0,0 \%$ & $0,0 \%$ & $1,9 \%$ \\
\hline & & \multicolumn{9}{|c|}{ Mean Absolute Percentage Error (MAPE) } & $0,0 \%$ & $0,0 \%$ & $0,5 \%$ \\
\hline
\end{tabular}


yang dihasilkan oleh CVS dengan hasil pengukuran nilai komponen RGB yang dihasilkan oleh photoshop. Dalam melakukan validasi CVS, citra digital dari hasil cetakan grafik warna Macbeth Colorchecker yang diambil menggunakan CVS lalu diukur dengan menggunakan aplikasi pengolah citra CVS, dan kemudian dibandingkan dengan hasil pengukuran photoshop. Pengukuran dilakukan dengan menggunakan 24 grafik warna Macbeth Colorchecker yang dicetak ke dalam kertas foto injek tipe Fujifilm Silky Satin Doff $235 \mathrm{~g}$ ukuran A4 $(210 \times 297 \mathrm{~mm})$ menggunakan printer Epson L360. Foto hasil cetakan ke-24 grafik warna Macbeth Colorchecker kemudian diambil menggunakan CVS dan diukur nilai komponen RGB-nya menggunakan aplikasi pengolah citra CVS. Hasil pengukuran nilai komponen RGB ke24 grafik warna Macbeth Colorchecker kemudian dibandingkan dengan hasil pengukuran nilai komponen RGB menggunakan photoshop. Hasil pengukuran citra Macbeth Colorchecker blue pada aplikasi pengolah citra CVS seperti pada tampilan Gambar 3.

Dalam proses validasi CVS, aplikasi pengolah citra dapat mengukur nilai RGB citra digital dari seluruh satuan luas piksel yang menyusun citra digital. Pengukuran nilai komponen RGB citra digital dengan photoshop dilakukan dengan menggunakan menu color sampler tool. Photoshop tidak dapat mengukur RGB dari seluruh satuan luas piksel yang menyusun citra digital. Pengukuran RGB dengan color sampler tool yang dimiliki

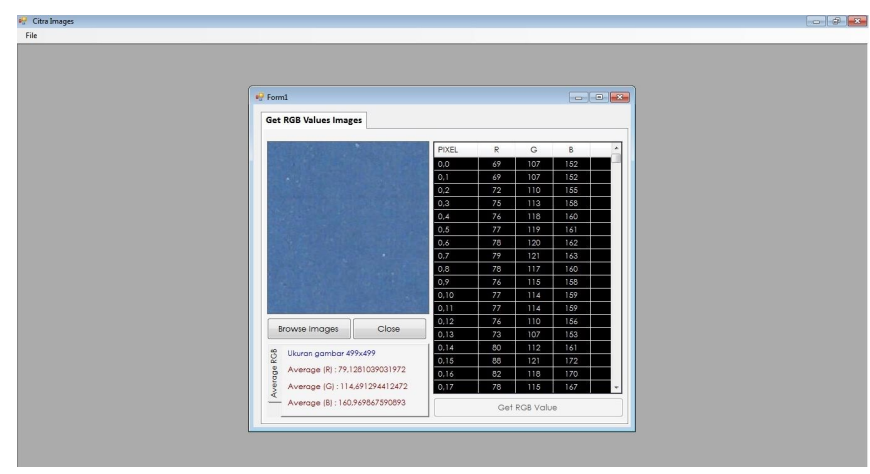

Gambar 3. Hasil pengukuran RGB citra grafik warna colorchecker blue menggunakan CVS oleh photoshop hanya dapat dilakukan pada titik piksel tertentu (maksimal 4 titik) sehingga nilai RGB yang digunakan adalah nilai rata-rata dari keempat nilai RGB pada titik yang diukur. Pengukuran RGB dari citra digital yang dihasilkan oleh CVS menggunakan photoshop seperti pada Gambar 4, sedangkan hasil validasi CVS dapat dilihat pada Tabel 2.

Berdasarkan pada hasil validasi, dapat dilihat bahwa hasil pengukuran nilai komponen RGB yang dihasilkan oleh CVS tidak berbeda nyata dengan pengukuran yang dihasilkan oleh photoshop. Kesalahan tertinggi dari hasil pengukuran RGB yang dihasilkan oleh CVS ada pada pengukuran komponen $\mathrm{R}$ sebesar 3,2\% dan terendah ada pada komponen B sebesar 0,5\%. Dari hasil validasi CVS dapat disimpulkan bahwa CVS dapat melakukan pengukuran nilai RGB pada kisaran 95\%. Hasil validasi ini sejalan dengan hasil penelitian Masithoh dkk., 2011 dimana hasil pengukuran nilai komponen RGB yang dilakukan oleh CVS tidak berbeda nyata dengan hasil pengukuran nilai komponen RGB yang dilakukan dengan photoshop.

\section{Aplikasi CVS dalam Pengukuran Warna Buah- buahan}

Penggunaan CVS dalam pengukuran warna buahbuahan dilakukan dengan mengambil citra digital buahbuahan menggunakan mini photo studio, kemudian mengolah citranya menggunakan aplikasi pengolah citra digital CVS. Buah yang menjadi objek pengukuran diletakkan di dalam mini photo studio, shutter kamera dioperasikan secara nirkabel (wifi) menggunakan laptop dan aplikasi Remote Imaging Edge. Ketika shutter kamera ditekan, maka kamera akan mengambil foto buah yang menjadi objek pengukuran kemudian secara langsung mentransfer citra digitalnya secara nirkabel ke dalam laptop. Citra digital dari buah yang menjadi objek pengukuran kemudian diolah menggunakan aplikasi pengolah citra CVS untuk mendapatkan nilai RGB hasil pengukuran warna buah. Citra digital yang akan diolah harus disegmentasi terlebih dahulu untuk memisahkan foto objek dari background (latar foto). Citra digital hasil segmentasi tersebut yang kemudian digunakan untuk

Tabel 2. Hasil validasi CVS pada pengukuran RGB dari grafik warna Macbeth Colorchecker blue

\begin{tabular}{llllllllc}
\hline & \multicolumn{9}{c}{ Photoshop } & CVS (B) & $\begin{array}{c}\text { Error } \\
(\mathrm{C}=\mathrm{B}-\mathrm{A})\end{array}$ & $\begin{array}{c}\text { \% Error } \\
\text { (Abs(C/A)*100\%) }\end{array}$ \\
\cline { 2 - 5 } R & 83 & 90 & 80 & 74 & 81,75 & 79,128 & $-2,622$ & $3,2 \%$ \\
G & 117 & 123 & 114 & 111 & 116,25 & 114,691 & $-1,559$ & $1,3 \%$ \\
B & 165 & 166 & 160 & 156 & 161,75 & 160,969 & $-0,781$ & $0,5 \%$ \\
\hline
\end{tabular}




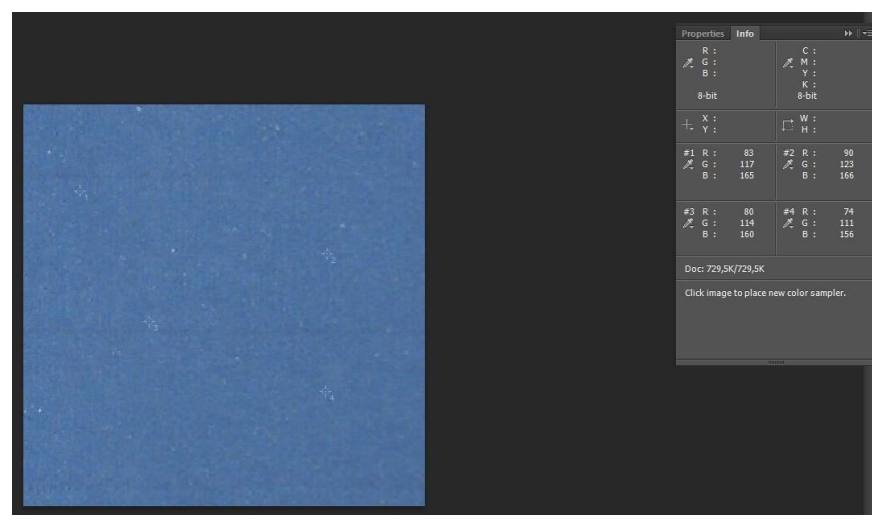

Gambar 4. Pengukuran RGB citra grafik warna Macbeth Colorchecker blue yang difoto oleh CVS menggunakan photoshop.

mengukur nilai RGB dari buah yang menjadi objek pengukuran.

Validasi hasil pengukuran warna buah yang dihasilkan oleh CVS divalidasi dengan menggunakan photoshop. Dalam proses validasi CVS, aplikasi pengolah citra dapat mengukur nilai RGB citra digital dari seluruh satuan luas piksel yang menyusun citra digital. Sedangkan pengukuran nilai komponen RGB citra digital dengan photoshop dilakukan dengan menggunakan menu color sampler tool. Photoshop tidak dapat mengukur RGB dari seluruh satuan luas piksel yang menyusun citra digital. Pengukuran RGB dengan color sampler tool yang dimiliki oleh photoshop hanya dapat dilakukan pada titik piksel tertentu (maksimal 4 titik) sehingga nilai RGB yang digunakan adalah nilai rata-rata dari keempat nilai RGB pada titik yang diukur.

Hasil validasi pengukuran warna buah-buahan menggunakan CVS tersaji di dalam Tabel 3. Hasil validasi menunjukkan bahwa tingkat kesalahan (error)

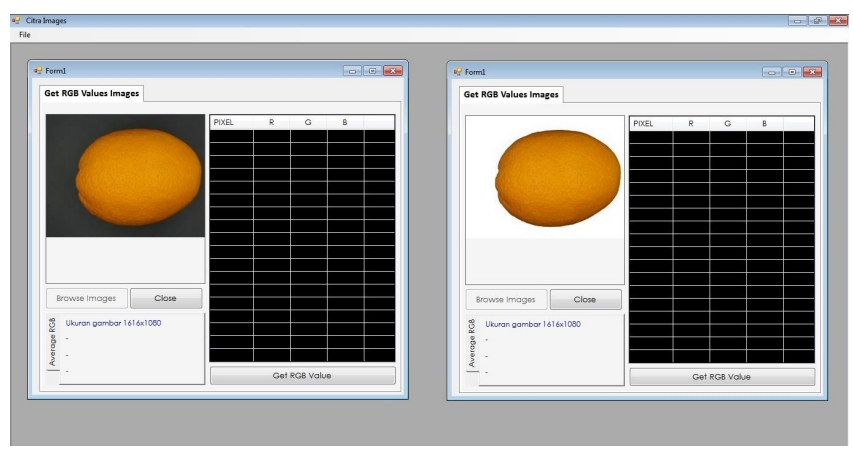

Gambar 5. Segmentasi citra untuk memisahkan objek dari background (latar foto).

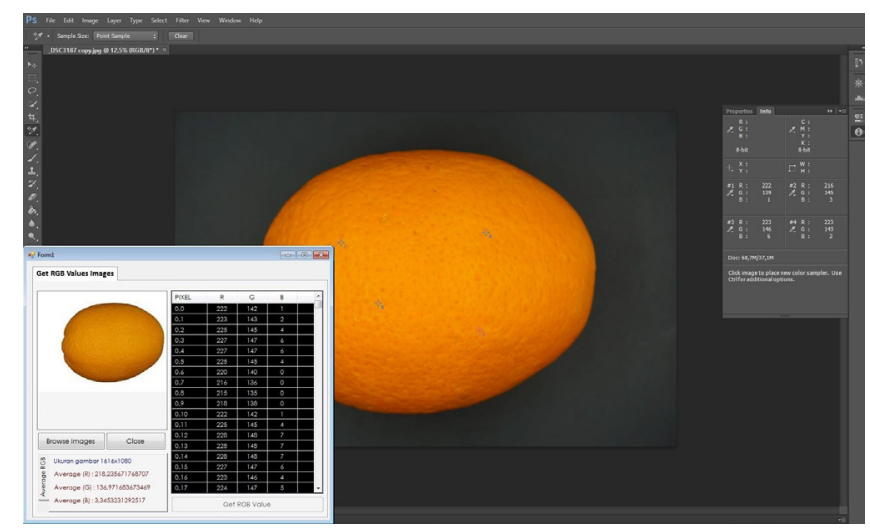

Gambar 6. Validasi hasil pengukuran warna CVS dengan hasil pengukuran warna pada Adobe Photoshop CS3.

tertinggi dari hasil pengukuran warna buah-buahan menggunakan CVS ada pada pengukuran jeruk Sunkist, dimana persentase kesalahan pengukuran komponen warna blue (B) mencapai $11,5 \%$. Hasil ini sejalan dengan hasil validasi pengukuran grafik warna Macbeth Colorchecker Orange yang sama-sama

Tabel 3. Hasil validasi pengukuran warna buah-buahan pada CVS dengan menggunakan Adobe Photoshop CS3

\begin{tabular}{|c|c|c|c|c|c|c|c|c|c|c|}
\hline \multirow[t]{2}{*}{ No } & \multirow[t]{2}{*}{ Kom oditas } & \multicolumn{3}{|c|}{ Photoshop (A) } & \multicolumn{3}{|c|}{ CVS (B) } & \multicolumn{3}{|c|}{$\begin{array}{c}\% \text { ERROR } \\
(\mathrm{C}=\mathrm{Abs}((\mathrm{B}-\mathrm{A}) / \mathrm{A}) * 100 \%)\end{array}$} \\
\hline & & $\mathrm{R}$ & $\mathrm{G}$ & $B$ & $\mathrm{R}$ & $\mathrm{G}$ & $B$ & $\mathrm{R}$ & G & $B$ \\
\hline 1 & Jeruk Sunkist & 221 & 143,2 & 3 & 218,2 & 136,9 & 3,3 & 1,25 & 4,38 & 11,50 \\
\hline 2 & Pisang Mas & 215,2 & 203 & 98 & 218,6 & 205,4 & 103,9 & 1,58 & 1,20 & 6,10 \\
\hline 3 & Lemon & 226,2 & 210,7 & 66,7 & 226,1 & 211,4 & 66,5 & 0,07 & 0,35 & 0,34 \\
\hline 4 & Apel Merah & 178,5 & 65 & 61,2 & 172,2 & 64,9 & 57,9 & 3,48 & 0,12 & 5,35 \\
\hline 5 & Jeruk & 218 & 142 & 7,2 & 212,1 & 133,0 & 7,1 & 2,71 & 6,30 & 1,97 \\
\hline 6 & Tomat Hijau & 170 & 169,2 & 75,7 & 172,9 & 174,6 & 79,7 & 1,74 & 3,18 & 5,23 \\
\hline 7 & Tomat Merah & 161,2 & 60,5 & 12,2 & 157,6 & 54,7 & 11,4 & 2,23 & 9,52 & 6,82 \\
\hline
\end{tabular}


memiliki tingkat kesalahan yang tinggi pada komponen warna blue (B) sebesar 1,8\%. Hasil validasi CVS juga menunjukkan bahwa hasil pengukuran warna buahbuahan menggunakan CVS tidak memiliki perbedaan yang signifikan dengan hasil pengukuran warna pada Adobe Photoshop CS3.

\section{KESIMPULAN}

Computer vision system (CVS) yang dikembangkan terdiri dari mini photo studio berdinding kanvas berwarna hitam berukuran $60 \times 60 \times 60 \mathrm{~cm}$ sebagai tempat pengambilan citra digital objek; 1 unit kamera Sony a6000 sebagai instrumen perekam citra objek; 2 unit lampu LED masing-masing berdaya 15 watt sebagai sumber cahaya; laptop dan aplikasi Remote Imaging Edge untuk mengendalikan shutter kamera secara nirkabel (wifi); laptop sebagai instrumen penyimpanan data, pengolah citra dan menampilkan data hasil ekstraksi citra; serta aplikasi pengolah citra digital yang diprogram dengan Bahasa pemrograman VB.Net 2008. Hasil validasi pengukuran nilai komponen RGB menunjukkan bahwa CVS yang dikembangkan memiliki tingkat akurasi $95 \%$.

\section{UCAPAN TERIMA KASIH}

Ucapan terima kasih disampaikan kepada Direktorat Jenderal Penguatan Riset dan Pengembangan, Kementerian Riset, Teknologi dan Pendidikan Tinggi Republik Indonesia melalui Program Hibah Penelitian Produk Terapan 2017.

\section{KONFLIK KEPENTINGAN}

Penulis menyatakan bahwa artikel ini asli hasil penelitian para penulis, hanya dipublikasikan pada jurnal ini, dan tidak ada konflik kepentingan.

\section{DAFTAR PUSTAKA}

Bhargava, A., \& Bansal, A. (2018). Fruits and vegetables quality evaluation using computer vision: A review. Journal of King Saud University - Computer and Information Sciences. https://doi.org/10.1016/j.jksuci.2018.06.002

Blasco, J., Cubero, S., Gómez-Sanchís, J., Mira, P., \& Moltó, E. (2009). Development of a machine for the automatic sorting of pomegranate (Punica granatum) arils based on computer vision. Journal of Food Engineering, 90(1), 27-34. https://doi.org/10.1016/j.jfoodeng.2008.05.035

Brosnan, T., \& Sun, D. W. (2004). Improving quality inspection of food products by computer vision - A review. Journal of Food Engineering, 61(1 SPEC.), 3-16. https://doi. org/10.1016/S0260-8774(03)00183-3

Costa, C., Antonucci, F., \& Menesatti, P. (2011). Shape Analysis of Agricultural Products : A Review of Recent Research Advances and Potential Application to Computer Vision. 673-692. https://doi.org/10.1007/s11947-011-0556-0

Elmasry, G., Cubero, S., Moltó, E., \& Blasco, J. (2012). Inline sorting of irregular potatoes by using automated computer-based machine vision system. Journal of Food Engineering, 112(1-2), 60-68. https://doi. org/10.1016/j.jfoodeng.2012.03.027

Elmasry, G., Kamruzzaman, M., Sun, D., Allen, P., Elmasry, G., Kamruzzaman, M., ... Allen, P. (2012). Principles and Applications of Hyperspectral Imaging in Quality Evaluation of Agro-Food Products : A Review Principles and Applications of Hyperspectral Imaging in Quality Evaluation of Agro-Food Products : 8398. https://doi.or $\mathrm{g} / 10.1080 / 10408398.2010 .543495$

Freitas, J., Gomes, S., \& Rodrigues, F. (2012). Applications of computer vision techniques in the agriculture and food industry : a review. 989-1000. https://doi.org/10.1007/ s00217-012-1844-2

Garrido-novell, C., Pérez-marin, D., Amigo, J. M., Fernándeznovales, J., Guerrero, J. E., \& Garrido-varo, A. (2012). Grading and color evolution of apples using RGB and hyperspectral imaging vision cameras. 113, 281-288. https://doi.org/10.1016/j.jfoodeng.2012.05.038

Girolami, A., Napolitano, F., Faraone, D., \& Braghieri, A. (2013). Measurement of meat color using a computer vision system. MESC, 93(1), 111-118. https://doi. org/10.1016/j.meatsci.2012.08.010

Iqbal, A., Valous, N. A., Mendoza, F., Sun, D. W., \& Allen, P. (2010). Classification of pre-sliced pork and Turkey ham qualities based on image colour and textural features and their relationships with consumer responses. Meat Science, 84(3), 455-465. https://doi.org/10.1016/j. meatsci.2009.09.016

Li, J., Rao, X., \& Ying, Y. (2011). Detection of common defects on oranges using hyperspectral reflectance imaging. Computers and Electronics in Agriculture, 78(1), 38-48. https://doi.org/10.1016/j.compag.2011.05.010

Lorente, D., Aleixos, N., Gómez-Sanchis, J., Cubero, S., GarcíaNavarrete, O. L., \& Blasco, J. (2012). Recent Advances and Applications of Hyperspectral Imaging for Fruit and Vegetable Quality Assessment. Food and Bioprocess Technology, 5(4), 1121-1142. https://doi.org/10.1007/ s11947-011-0725-1

Masithoh, R. E., Rahardjo, B., Sutiarso, L., \& Hardjoko, A. (2011). Pengembangan computer vision system sederhana untuk menentukan kualitas tomat. AgriTECH, 31(2).

Pallottino, F., Menesatti, P., Costa, C., Paglia, G., de Salvador, F. R., \& Lolletti, D. (2010). Image analysis techniques 
for automated hazelnut peeling determination. Food and Bioprocess Technology, 3(1), 155-159. https://doi. org/10.1007/s11947-009-0211-1

Pascale, D. (2006). RGB Coordinates of the Macbeth Color Checker. The BabelColor Company, 1-16. Retrieved from http://www.babelcolor.com/download/RGB Coordinates of the Macbeth Colorchecker.pdf

Patel, K. K., Kar, A., Jha, S. N., \& Khan, M. A. (2012). Machine vision system : a tool for quality inspection of food and agricultural products. 49(April), 123-141. https://doi. org/10.1007/s13197-011-0321-4

Pathare, P. B., Opara, U. L., \& Al-Said, F. A. J. (2013). Colour Measurement and Analysis in Fresh and Processed Foods: A Review. Food and Bioprocess Technology, 6(1), 36-60. https://doi.org/10.1007/s11947-012-0867-9

Razmjooy, N., Mousavi, B. S., \& Soleymani, F. (2012). A real-time mathematical computer method for potato inspection using machine vision. Computers and Mathematics with Applications, 63(1), 268-279. https:// doi.org/10.1016/j.camwa.2011.11.019

Russ, J. C. (2004). Image analysis of food microstructure. CRC press.

Teena, M., Manickavasagan, A., Mothershaw, A., Hadi, S. El, \& Jayas, D. S. (2013). Potential of Machine Vision Techniques for Detecting Fecal and Microbial Contamination of Food Products : A Review. 1621-1634. https://doi.org/10.1007/s11947-013-1079-7
Vidal, A., Talens, P., Prats-Montalbán, J. M., Cubero, S., Albert, F., \& Blasco, J. (2013). In-Line Estimation of the Standard Colour Index of Citrus Fruits Using a Computer Vision System Developed For a Mobile Platform. Food and Bioprocess Technology, 6(12), 3412-3419. https:// doi.org/10.1007/s11947-012-1015-2

Wang, Y., Cui, Y., Chen, S., Zhang, P., Huang, H., \& Huang, G. Q. (2009). Study on fruit quality measurement and evaluation based on coloridentification. 2009International Conference on Optical Instruments and Technology: Optoelectronic Imaging and Process Technology, 7513, 75130F. https://doi.org/10.1117/12.839698

Wu, D., \& Sun, D. W. (2013). Colour measurements by computer vision for food quality control - A review. Trends in Food Science and Technology, 29(1), 5-20. https://doi.org/10.1016/j.tifs.2012.08.004

Xiaobo, Z., Jiewen, Z., \& Yanxiao, L. (2007). Apple color grading based on organization feature parameters. Pattern Recognition Letters, 28(15), 2046-2053. https:// doi.org/10.1016/j.patrec.2007.06.001

Zhang, B., Huang, W., Li, J., Zhao, C., Fan, S., Wu, J., \& Liu, C. (2014). Principles, developments and applications of computer vision for external quality inspection of fruits and vegetables: A review. FRIN, 62, 326-343. https:// doi.org/10.1016/j.foodres.2014.03.012 